\title{
When is a country multinational? Problems with statistical and subjective approaches
}

\author{
Stojanovic, N
}

\begin{abstract}
Many authors have argued that we should make a clear conceptual distinction between mononational and multinational states. Yet the number of empirical examples they refer to is rather limited. France or Germany are usually seen as mononational, whereas Belgium, Canada, Spain and the UK are considered multinational. How should we classify other cases? Here we can distinguish between (at least) two approaches in the literature: statistical (i.e., whether significant national minorities live within a larger state and, especially, whether they claim self-government) and subjective (i.e., when citizens feel allegiance to sub-state national identities). Neither of them, however, helps us to resolve the problem. Is Italy multinational (because it contains a German-speaking minority)? Is Germany really mononational (in spite of the official recognition of the Danes and the Sorbs in some Länder)? On the other hand, is Switzerland the "most multinational country" (Kymlicka)? Let us assume that there is no definite answer to this dilemma and that it is all a matter of degree. There are probably few (if any) clearly mononational states and few (if any) clearly multinational states. Should we abandon this distinction in favour of other concepts like "plurinationalism" (Keating), "nations-within-nations" (Miller), "postnational state" (Abizadeh, Habermas), or "post-sovereign state" (MacCormick)? The article discusses these issues and, in conclusion, addresses the problem of stability and shared identity "plural" societies.
\end{abstract}

DOI: https://doi.org/10.1111/j.1467-9337.2011.00484.x

Posted at the Zurich Open Repository and Archive, University of Zurich

ZORA URL: https://doi.org/10.5167/uzh-53057

Journal Article

Accepted Version

Originally published at:

Stojanovic, N (2011). When is a country multinational? Problems with statistical and subjective approaches. Ratio Juris, 24(3):267-283.

DOI: https://doi.org/10.1111/j.1467-9337.2011.00484.x 


\section{When is a country multinational? Problems with statistical and subjective approaches ${ }^{1}$}

\section{NENAD STOJANOVIC}

Abstract. Many authors have been arguing that we shall make a clear conceptual distinction between mononational and multinational states. Yet the number of empirical examples they refer to is rather limited. France or Germany are usually seen as mononational, whereas Belgium, Canada, Spain and the UK are considered multinational. How shall we classify other cases? Here we can distinguish between (at least) two approaches in the literature: statistical (i.e., if significant national minorities live within a larger state and, especially, if they claim self-government) and subjective (i.e., when citizens feel allegiance to sub-state national identities). None of them, however, helps us to resolve the problem. Is Italy multinational (because it contains a German-speaking minority)? Is Germany really mononational (in spite of the official recognition of the Danes and the Sorbs in some Länder)? On the other hand, is Switzerland the example of the "most multinational country" (Kymlicka)? Let us assume that there is no definite answer to this dilemma and that it is all a matter of degree. There are probably few (if any) clearly mononational states and few (if any) clearly multinational states. Should we abandon this distinction in favour of other concepts like "plurinationalism" (Keating), "nations-within-nations" (Miller), "postnational state” (Abizadeh, Habermas) or "post-sovereign state" (MacCormick)? The article discusses these issues and, in its conclusion, it addresses the problem of stability and shared identity "plural" societies.

The distinction between mononational states (also called "uninational" or "single nation-states") and multinational states pervades the current literature on nationhood, democracy and multiculturalism (see, e.g., Kymlicka 1995, Requejo 1999, Gagnon 2001, Keating 2001).

For example, this distinction is central to Will Kymlicka's seminal work on multiculturalism. His work being largely embedded in the contemporary political theory, the distinction between mononational and multinational states bears normative connotations. Yet Kymlicka constantly illustrates his point by referring to empirical examples. For example, Switzerland, Belgium, Canada and Spain are considered as multinational, whereas Germany, France or England are seen as “paradigmatic [single] nation-states” (Kymlicka 1997, 29).

Previous drafts of this paper were presented in Belfast (Conference “Beyond the Nation?", Queen's University, September 2007), London (ASEN Annual Conference, April 2008), Florence (Workshop on Nationalism and Democracy, EUI, November 2009, and Conference "Legal Reasoning and European Law: the Perspective of Neil MacCormick", EUI, May 2010), and New York (ASN Conference April 2010). I am indebted to audiences of these events for their constructive criticism. A special thanks goes to Rainer Bauböck, Hudson Meadwell, Alan Patten for their written comments. All errors are mine. 
According to Neil MacCormick (1996, 554), Kurdistan, Slovakia, Catalunya, Euskadi, Wales and Scotland, are "obvious nations", even if they are not states - that is, they are "non-state nations" (MacCormick 1996, 562, footnote 17). In other words, he makes a clear distinction between nation and state:

Manifestly [nations] are not necessarily identical with states, for while there are some nation-states, there are some states that are not nations (e.g., the former USSR) and some nations that are not states (e.g., the Basque nation, whose members inhabit areas within two adjacent states). States are political entities that have a legal definition. [...] On this view, the United Kingdom is certainly a state; equally certainly, none of England, Scotland, Wales, or Northern Ireland is a state. Yet most people would consider that "England", "Scotland," and "Wales" are the names of nations. (MacCormick 1999a, 190)

Even if MacCormick himself does not explicitly use the term "multinational," we can assume states that include such "non-state nations" (i.e., United Kingdom, Spain) shall be called multinational.

But if we better look at the empirical evidence, this simple typology is all but unproblematic. What criteria can we use in order to establish the "multinational" character of a country? There are (at least) two approaches that we could spot in the contemporary literature on nationhood. I will call them (a) statistical, and (b) subjective.

This article first discusses the two approaches and argue that they are not particularly helpful for distinguishing mononational from multinational states. In order to illustrate my point, I will often refer to a number of empirical examples. The examples of Switzerland and Germany are particularly interesting since the latter is typically considered as the "most multinational country" (Kymlicka 1995, 18)2, whereas the former is often cited as a single nation-state and its mononational character seems undisputed in the literature. 3

In the final section of the paper, I will discuss the importance of shared identity which is often seen as a condition for stability of any democratic polity (mono or multinational). This will be done in the light of the (spurious) distinction between mononational and multinational states.

\section{Statistical Approach}

According to Pierre van den Berghe $(2005,116-7)$ "90 per cent or more" of the existing states cannot be considered "nation-states." Indeed, the very idea of nation-state is a "fiction" that ruling

2 See also Requejo (1999). Note, however, that for MacCormick (1999a, 191) the Swiss constitute a single nation.

For Watts (2000, 44) Germany is a "mono-ethnic federation." For Keating (2001, 127) it is a "nationally homogeneous" state. A similar view is shared by Stepan (2001, 327), Gagnon (2001, 323), and Burgess (2006, 108). 
elites of many countries (France, the United States, etc.) "have a mutual interest in maintaining." The author further claims that "[o]f the modern states, only Switzerland, it seems, sees no need to apologise for not being a nation-state, or to pretend to strive to become one. It seems quite happy to have escaped 'modernity."'

In the same volume Connor $(2005,40-1)$ affirms that there is certainly a Welsh, Flemish, or Basque nation; but there is no American, Argentinian, Belgian, British, Indian, Indonesian, or Spanish nation. Indeed, there seems to be no nation-state in the whole Anglo-Saxon family of states and none among the Latin American states ("with the possible exception of Costa Rica"). Further, "very few of Europe's states" could qualify as nation-states, since all are "ethnically heterogeneous." 4

These views nicely illustrate what we can call the statistical approach to mononational v. multinational question. If there is a statistical evidence that a country is composed of different (linguistic, religious, ethnic, etc.) groups, then it cannot be a mononational state and must be considered as multinational.5

Yet I do not think that this approach is useful for distinguishing mononational from multinational states. Take the example of Germany. It is not clear why should we see it as mononational, considering a large percentage of Turkish-speaking citizens (with or without German citizenship), as well as many other citizens of foreign origin (Greeks, Italians, former Yugoslavs, Poles, etc.). 6

The multinationalists have a ready answer to this objection: the presence of immigrants and/or of citizens of migrant origin does not count. According to Kymlicka's (1995) terminology, a state like Germany would be considered as "polyethnic" but not as multinational. This author provides many normative reasons which seem to justify the exclusion of immigrant ("ethnic") groups from the mononational v. multinational dichotomy. What really counts is the presence of historically anchored "national minorities." Only they have a claim for self-government within the larger state.

This approach is not unproblematic (see, e.g., Young 1997), but let us accept it for the sake of argument. In other words, if we exclude the Turks and other immigrant groups from the definition

4 And it goes without saying that, for Connor $(2005,41)$, the very idea that there is $a$ Swiss nation is a pure absurdity: "The Swiss example is a telling demonstration of how grouping two essentially different and often competing identities under a single rubric can vitiate analysis. There is most certainly a Swiss civic identity (again, call it patriotism, civic consciousness, statism or etatism), although it is certainly stronger among the German than among the French Swiss. But [Anthony D. Smith's $(2004,200)$ ] assertion that 'the Swiss as a whole feel they have been a nation for many generations' is simply not the case."

5 Generally speaking, such accounts often conflate the terms "multiethnic" and "multinational."

6 In 2007 there were 1.71 million Turkish citizens, at least 0.71 millions former Yugoslavs (excluding Slovenia and Macedonia), 0.53 million Italians, 0.38 million Poles, and 0.29 million Greeks in Germany. To these figures we should add, for example, the German citizens of Turkish origin. Only in the 2004-2007 period 139,375 Turkish citizens acquired the German citizenship. (Source: Statistisches Bundesamt Deutschland.) According to the World Directory of Minorities and Indigenous Peoples, there were 1.9 million (2.3 percent) Turks and Kurds, and 1.1 million (1.3 percent) Yugoslavs in Germany, in 2002. 
of nationhood in Germany, would this country still count as mononational? I don't think so. There are in fact at least three autochthonous national groups in Germany with a longstanding presence within the current boundaries of the German federation: the Danes, the Sorbs and the Frisians. They are officially recognised as "national minorities" in the German legal framework (see Reinhardt 2009).

Let us try to anticipate the reaction of a multinationalist who might still want to insist that Germany is not multinational. She would claim that (a) the Danes, the Frisians and the Sorbs are numerically too small (around 50,000-70,000 each, in a country of 82 million)7, (b) their presence is politically irrelevant to the definition of German nationhood (for example, because they do not claim self-government or separate institutions).

The argument (a) is interesting because it opens up the discussion over the minimal statistical threshold, ranging between 0 and 50 percent, which should enable us to determine when is a country multinational. Of course, there is no objective way for choosing such a threshold and every decision will bear a degree of arbitrariness. I propose to establish it by looking at national minorities which status as nations within a lager multinational state is largely undisputed in the literature, like the Basques and the Welsh. The population of the Basque Country makes up 4.9 percent (2.04 out of 41.06 million) of the Spanish population.8 (However, not all inhabitants of the Basque Country consider themselves as Basques, and not all Basques live in the Basque Country.) ${ }^{9}$ On the other hand, the population of Wales represents also 4.9 percent within the United Kingdom, whereas that of Scotland is 8.4 percent. 10

Therefore, the appropriate threshold could be set at 4-5 percent. As a result, we could not define Italy as multinational because the percentage of German-speaking Italian citizens within the population of Italy is too small: 290,000 or 0.5 percent of the population. 11

Yet if we rely on ethnic statistics we are on shaky ground. Who should be considered as a "Basque"? Does he or she must speak Basque? Fluently or only partially? Should we consider only the Basques from Spain, or only the Basques from the Basque Country (i.e., autonomous region of the Kingdom of Spain)? Or should we also include the Basques from France? And those from the

\footnotetext{
Source: World Directory of Minorities and Indigenous Peoples - Germany: Overview.

8 As of 1 January 2009. Source: Instituto Nacional de Estadística (www.ine.es/prensa/np551.pdf). Spanish citizens only.

9 According to the official 2007 report of Spain concerning the European Charter for Regional or Minority Languages (ECRML), 80 percent of the Basques live in the Basque Country (p. 17). On the other hand, a half of the population of the Basque Country (49.6 percent, or 984,656 in 2001) speak Spanish only, whereas about a third (32.3 percent, or 639,296 in 2001) are bilingual (p. 16). The remaining 18.2 percent (or 240,426) are considered as "passive bilinguals." In other words, in 2001 there were 879,722 Basque speakers in the Basque Country, which represents 1.9 percent of the Spanish population in the same year $(44,108,530)$. This figure includes foreigners, but excludes Basque speakers who live in Spain but outside the Basque Country.

10 As of 30 June 2008 (estimation). Source: Office for National Statistics (www.statistics.gov.uk). These figures include foreign residents. The same disclaimer as in the case of the Basque Country applies.

11 Estimate 2001-2009. Source: Istituto Nazionale di Statistica.
} 
diaspora?

This ethnic dilemma constitutes, I believe, a problem for multinationalist authors. Indeed, most of them clearly situate themselves within liberal tradition. They explicitly adhere to liberal or "civic" concepts of nation and nationalism. Kymlicka (1995), for example, advocates a "liberal theory of minority rights", whereas MacCormick (1996, 566) speaks of a "primarily civic nationalist conception of membership in a nation" which seems to him "perfectly compatible with one defensible version of liberalism." In sum, their adherence to liberal principles should logically lead them to exclude the use of ethnic statistics for establishing the mono or multinational character of a state. If Basques are a nation then, from a liberal perspective, their nationhood should include all inhabitants of the Basque country. 12

As a further illustration of difficulties that we encounter by using the statistical approach, consider also the case of Austria (see also Bauböck 2001, 46-7). The official 2007 report of Austria for the ECRML lists six "national minorities" or Volksgruppen: Burgenland-Croatian, Slovene, Hungarian, Czech, Slovak and Roma.13 Yet it is not clear what the size of these groups is. The Austrian report underlines this problem very clearly (pp. 22-23):

One must, however, clearly bear in mind that these statistics can only provide approximate values, as the Austrian census does not inquire about affiliation with a national minority, but about the language actually used in everyday life. Multiple indications are admissible. The number of persons using a special language must, however, not be equated to the number of persons belonging to a national minorities. The national minorities themselves refuse to participate in statistical investigations that ask for a commitment to a national minority.

Only after this remark does the Austrian report provide the numbers of speakers of minority languages, which range from 3,343 (Slovak) to 25,884 (Hungarian) in 2001 (p. 23). 14 According to the Austrian data there were 17,953 Slovenes living in Austria in 2001, but only 13,225 are considered as autochthonous (born within Austria). The government of the Republic of Slovenia, however, estimates that up to 31,500 autochthonous Slovenes live in the neighbouring Austria.15

Considering the difficulties of the option (a) of the statistical approach, we shall see if the option (b) can do the job. In fact, for an author like Stepan (2001, 327), the existence of "significant political groups who would like to build political sovereignties, or an independent state or states,

12 This is precisely the evolution that could be observed in Quebec, where the Quebec nationalists gradually abandoned the ethno-linguistic and religious definition of the Québécois nation (i.e., only French-speakers of French origin, and possibly only Catholics, were considered as Québécois), in favour of an inclusive civic conception.

13 I use the term "national minority" because it is the official (Austrian) translation of the German term Volksgruppe, as stated in the Austrian report to the ECMRL (p. 9). Bauböck (2001, 47), however, speaks of "ethnic minority."

14 These figures include persons who were born outside Austria. The number of Austrian citizens is close to 7.5 million.

15 Source: Republic of Slovenia, Government's Office for Slovenians Abroad (www.uszs.gov.si/en; accessed 1 November 2009). 
around these territorially based differences" is one of the two elements defining a multinational state. 16

It might be easier, thus, to identify nationalist movements who demand self-government for the populations they claim to represent. Yet should we consider only those movements who demand full independence? Or also those who simply claim forms of territorial autonomy and/or partial sovereignty within a given state? Further, it is not clear how much support should a movement enjoy within the population it aims to represent, in order to be considered as a reliable criterion.

These are important questions. If we do not have a clear answer, we risk (once again) to blur the distinction between mononational and multinational states. Are Corsicans a "nation" and is the Corsican autonomist movement sufficiently strong in order to declare France a "multinational" country? Is Italy multinational because of the Lega Nord, which demands independence for "Padania" and holds 5 to 16 percent of the electorate in the northern regions of Italy?17

\section{Subjective Approach}

The second approach consists in looking at the existence of multiple national identities within a given state. In fact, common to most multinationalist accounts is the claim that citizens of multination states have multiple (or plural) national identities.

"Multiple identities characterize multinational and multilingual states", claims, for example, Resnick (2006). This means that the citizens feel allegiance both to the state and to their (sub-state) nation. In order to prove this claim the multinationalists typically cite the results of the "surveys of national identity" in which people were asked to answer the questions like: "Do you feel only Belgian, more Belgian than Flemish, equally Flemish and Belgian, more Flemish than Belgian, or only Flemish?"18

Kymlicka also often cites "recent polls" in order to prove his theses. "91 per cent of the residents of Puerto Rico think of themselves as Puerto Ricans first, and Americans second [which shows that they] do see themselves as Americans, but only because this does not require abandoning their prior identity as a distinct Spanish-speaking people with their own separate political community" (Kymlicka 1995, 190). Further, "over half of Quebeckers attach priority in their self-

16 The first element is the existence of "territorially based different linguistic identities that are often compounded with ethnic and/or religious and/or cultural identities" Stepan $(2001,327)$.

17 The Lega Nord obtained 15.8 percent of the vote in Lombardy, 14.7 percent in Veneto, 12.9 percent in Friuli Venezia Giulia, 8.5 percent in Piedmont, 4.8 percent in Emilia Romagna, and 4.7 percent in Liguria. 2005 regional elections.

18 Keating (2001, chap. 3), for example, dedicates a whole chapter of his 2001 book on "plurinational" states to this issue, by displaying the results of such surveys made in Canada (Quebec), the United Kingdom (Scotland, Wales, Northern Ireland), Belgium (Flanders, Wallonia), and Spain (Catalonia, Basque Country). 
identify to their status as Quebec citizens, compared with 15 to 30 per cent who attach priority to Canadian citizenship" (Kymlicka 1998, 171).

Connor $(2005,41)$, too, uses the surveys of national identity attitudes are in order to show, for example, that even in Switzerland the "ethnic division" is now perceived as "important and growing", since "a latitudinal poll has shown that a substantial majority of young French Swiss identify more closely with the French of France than with their co-citizens; another poll shows that a strong majority of the French Swiss feel that their linguistic or cantonal identity is more important than their identity as Swiss."

Does this approach really help us to distinguish between mononational and multinational states? I do not think so. Let us take, as the starting point, the case of Switzerland cited by Connor.

It would be relatively easy to contrast Connor's point by displaying the results of other surveys that do not corroborate his claims. For example, if asked to indicate their three main identities (among municipality, canton, linguistic community, Europe, and the world), 74 per cent of the French-speaking Swiss included "Switzerland" and only 50 per cent "[French-speaking] linguistic community" in their answer. And if asked what is their primary attachment, 25-30 percent of French speakers answered "Switzerland", whereas only 14-15 percent indicated "Suisse romande" [Frenchspeaking Switzerland] (Kriesi et al. 1996, 55-6).

The Swiss survey results also contradict another important argument advanced by some (but not all) multinationalists. In fact, authors like Kymlicka, MacCormick, Requejo or Resnick do not simply affirm that in multination states people have multiple identities. They also claim that members of minority sub-state nations feel in the first place allegiance to their sub-state nation. 19 The identity with the multination state is subordinated to the sub-state national identity. The inverse is said to be true for members of the majority nation.

Members of majority nationalities define themselves primarily or exclusively in terms of the larger national identity. Members of majority nationalities have thicker allegiances to their larger nation state that they generally dominate, while members of minority nationalities have thinner allegiances to those same nationstates. Much of the conflict within multinational states is between these thicker and thinner versions of identity. (Resnick 2006)

19 For Kymlicka (1995) the nation is the "primary focus of identity" and for Requejo $(1999,266)$ national identity is "normally one of the basic components of self-identity." MacCormick - while recognising the existence of multiple identities, for "[p]robably nobody identifies solely with national attributes" - also seems to share the view that $a$ given national identity often prevails over other identities and that it deserves a special respect. "[I]f for many humans as humans are today, individuality includes subjective commitment to some national culture perceived as such, then respect for humans as contextual individuals must include respect for their sense of nationality among other things" (MacCormick 1999b, 76; emphasis added). 
This claim, too, does not hold for Switzerland.20 On the scale of attachment to Switzerland mentioned before, the German-speaking Swiss, the majority linguistic group, display the same score (4.9) as the largest minority group (French speakers). The smaller linguistic minority (Italian speakers) show an even higher attachment to the Swiss state (5.1). Kriesi et al. (1996, 56), therefore, speak of a "nice unanimity" among the linguistic groups on this issue. If asked to declare their "primary attachment" a higher percentage of German speakers (43-44 percent) than French speakers (25-30 percent) indicate "Switzerland." But on a more realistic question that takes better into account the multiple identities of the citizens - three most important identities - roughly threequarters of German, French and Italian speakers answer "Switzerland", with percentages ranging between 73 and 82 .

Generally speaking, however, I wish to question the very relevance of such surveys for the normative and analytical importance of the distinction between mononational and multination states. Of course, social scientists cannot avoid taking into account social reality. They cannot speak of people's identities without having a clue about what individuals "really think" about their personal identity. But for at least three reasons we must be very careful when using and interpreting such surveys, especially if they deal with so delicate, personal, and context-dependent issues like identity.

First, the individual response to a survey question like "Do you feel only Belgian, more Belgian than Flemish, equally Flemish and Belgian, more Flemish than Belgian, or only Flemish?" is all but straightforward. As John Breully (cited in Ichijo and Uzelac 2005, 49) said in a comment on Connor (2005): "I do disagree fundamentally with certain aspects of Walker Connor's views. For example, I find it impractical to define a nation in terms of what people really feel, because I don't even know what I really feel."

Indeed, most people experience a continuous shift of their identity focus. The very idea that there are multiple identities stands in contradiction with a survey question that tries to discover people's allegiances by giving them a limited range of options. Further, a response to such a question is clearly dependent on the context. In the 1990s the identification with Switzerland among French speaker might have been lower than in the 2000s, in virtue of the large impact that the 1992 referendum on the Swiss membership to the European Economic Area had in the media and on the relations between French and German speakers (see Büchi 2000). It is also dependent on how and by whom a survey is conducted. Respondents could also object that their prime identities are absent from the options included by the survey. A fervent Catholic could object that the religious identity is totally absent, whereas an inhabitant of the downtown Zurich or Geneva could question the absence

20 Indeed, it does not hold for other "multination" states, either. In Belgium "it is the Francophones, numerically the minority, who are more strongly attached to a single Belgian identity" (Keating 2001, 101). 
of the option "urban v. rural" identity.

Even if the survey is limited to the "national identity" only, we still face major methodological problems. For instance, no survey mentioned above took into account the identities of foreign residents of the "multination" states. And even if the enquiry is limited to the full-time citizens of a "multination" state, it still ignores the fact that an important proportion of them were citizens of other states at the time of their birth, or have foreign-born parents. In fact, most of them have more than one passport. These considerations are important in many countries which considered as multinational. The United Kingdom, Belgium, and Canada are all immigrant societies, and in the past years Spain has been rapidly becoming one. In other words, if asked "Do you feel only Belgian, more Belgian than Flemish (or Walloon), equally Flemish (or Walloon) and Belgian, more Flemish (or Walloon) than Belgian, or only Flemish or Walloon?", a Belgian citizen might answer: "I feel only Kurdish."

The second important problem concerning the surveys of national identity is directly related to the first one. It points at the difficulties in the interpretation of the results. The way how we interpret empirical data is a general problem in every science. Moreover, far from being objective, it is usually highly dependent on the theory that a scholar advocates or, generally speaking, on her Weltanschauung.

When [scientists] do experiments or collect data to support their theories, other scientists, often those attached to different theories, deny that the evidence shows any such thing. [...] However much data you have, [the physicist Pierre] Duhem said, there will be many theories that explain it equally well. Theories, to use the jargon, are underdetermined by the evidence. (Appiah 2007, 39-40)

If Duhem's thesis holds for experimental, natural sciences, it is especially relevant in the field of social sciences. And, I argue, it is even more so with regard to the use of surveys in social sciences which object of enquiry are such delicate concepts like "identity." The reader might have noticed that in order to invalidate Connor's or Resnick's theses and their interpretation of the surveys of national identity in the "multination" states I have relied on other available surveys conducted in Switzerland. Now in order to invalidate my claim that Switzerland is best considered a nation-state Resnick, for instance, could use the same surveys and argue that, after all, the difference of some 15-20 percentage points between the "primary attachment" of German and French speakers is not irrelevant and that it confirms his thesis that members of majority nationalities [i.e., presumably the German speakers in Switzerland] have thicker allegiances to the larger nation-state, while members of minority nationalities [i.e., French speakers] have thinner allegiances. But such endless tugs-ofwar are, I believe, fruitless and belong more to the kindergarten than to academy. 
Nevertheless, I do not say that social scientists should completely ignore the results of the surveys, even those concerning national identity. Simply, I argue that their use should be mainly illustrative and that we cannot build a theory of (multi)nations by taking the surveys as one of its constitutive blocs. They cannot be one of the pillars of the house; at best they are the smoke that comes from the chimney: invisible during the warm winter days, not to speak of other seasons, we can spot it in cold mornings or in late evenings, or during occasional tempests, and even then we cannot say with certainty whether it is white, dark, or something in between.

The third and final objection to this argument concerns its very relevance for the analytical distinction between mononational and multinational states. Advocates of multinationalism use this argument in order to show that the kind of national identity professed by the citizens of multination states is something peculiar to such states. Let me recall what Resnick (2006) said: "Multiple identities characterize multinational and multilingual states."

Now, I believe that multiple identities characterise, indeed, citizens of all states. This is a prima facie argument that does not need any survey results: it is an anthropological fact. Multinationalists could argue, however, that the type of multiple identities in a multination state is a special one. It is a multiple national identity. Here we risk entering the endless semantic debate on "what the national identity is." I do not wish to engage in such a debate and limit my focus upon the fact that all national identities identified by multinationalists are territorially defined. This is clear in the case of national identities defined in terms of larger states (Canada, Spain, etc.). But it is also clear that the first element for identifying the sub-state national identities (Scotland, Wallonia, etc.) is territory. The latter may have a secondary element of definition in terms of linguistic identity, but it is an optional, not an obligatory element.21

Now we need to ask: is this dual or plural territorial/national identity really something special that characterises only multinational (and/or multilingual) states? Is it not something that characterises, again, all countries (with the possible exception of small republics or monarchies like Lichtenstein, Monaco, San Marino, and Singapore)? One is Carinthian and Austrian, Bavarian and German, Savoyard and French, Sicilian and Italian, Californian and American, Dalmatian and Croatian, Tokyan and Japanese, Punjabi and Indian, and so on. It is not only a quantitative remark. It is also qualitative. Would a survey question "Do you feel only German, more German than Bavarian, equally German and Bavarian, more Bavarian than German, or only Bavarian?” produce substantially different results in terms of intensity of territorial/national identities in Bavaria, than in Scotland, Catalonia, Quebec, or Wallonia? Would this mean that Germany, too, is multinational? According to the subjective approach (as described here) we may be tempted to answer

21 For example, most Scots speak English, whereas in Quebec Anglophones or other non-Francophone Quebeckers may, and often do, feel at least some identity allegiance to Quebec. 
positively. 22

To sum up, the subjective approach seems to me too weak in order to support - analytically, normatively, and empirically - the distinction between mononational and multination states. If we opt for that approach most states could be declared multinational.

\section{Stability and Shared Identity: A Fundamental Challenge}

In previous sections we have seen that the statistical and subjective approaches do not provide a clear answer to the question "when is a country multinational?". We have come to this conclusion by examining a number of empirical examples. Now, I would like to turn to an important normative point which is central to the mononational v. multinational dichotomy. It concerns the problem of shared identity and stability in a multinational state. The dilemma is nicely formulated by Kymlicka:

The sense of being a distinct nation within a larger country is potentially destabilizing. On the other hand, the denial of self-government is also destabilizing, since it encourages resentment and even secession. Concerns about social unity will arise however we respond to self-government claims. A fundamental challenge facing liberal theorists, therefore, is to identify the sources of unity in a democratic multination state. (Kymlicka 1995, 192)

Indeed, "[a]round the world, multination states are in trouble. Many have proven unable to create or sustain any strong sense of solidarity across ethnonational lines" (Kymlicka 2001, 91).23

This dilemma is not new. Already de Tocqueville, in Democracy in America, stressed that "federalism seems to require a degree of national homogeneity, or at least a strong commitment to shared values, to balance the centrifugal forces of decentralization" (cited in Keating 2001, 102).

Multinationalists believe that the multinational state is able solve this dilemma, since its citizens can develop a sense of allegiance both to the sub-state nation and to the multination state. This, however, is not an easy task, as Abizadeh notes:

22 According to Anthony Rowley, an expert of the dialects in Bavaria, "[ $t$ ]he efforts, such as those by the Association for the promotion of the Bavarian language and dialects, do demonstrate that there is a Bavarian identity, which is strongly defined through language" (my translation from German). Cited in a speech of the Bavarian minister for education and religion ["Pflege und Erhalt der in Bayern gesprochenen Mundarten"] available on-line at www.km.bayern.de (accessed 1 November 2009).

23 As Abizadeh $(2004,248-9)$ observes "[the] problem of explaining integration and solidarity in the absence of a common national identity has visibly haunted Kymlicka's most recent work since endorsing the cultural nationalist thesis." 
[T]his strategy works liberal nationalists into a bind. First, having granted the cultural nationalist thesis, they are at a loss to explain how the functionalist requirements of liberal democracy could be met at the federal level. Their assumption, after all, is that "nationhood still functions as the basis for the solidarity and trust needed to sustain a democratic rule" (Kymlicka 2001, 238-9). Since this common nationality is precisely what the multination state lacks, its status becomes rather problematic on democratic grounds. The real site of democratic participation and legitimacy must shift downward, away from the federal political unit. In other words, multination federalism becomes, on this theory, a curtailment - and not an institutional expression - of democratic practice. Federalism and democracy become competing principles of legitimacy. Given the commitment to democracy, the result is that, as Kymlicka (2001, 113-6) puts it, the very success of multination federalism sews the seeds of its own break-up. (Abizadeh 2004, 246)

Further, the fact that multinationalists underline the necessity that Quebec or Catalonia had to be recognised as "nations" - and not merely as "peoples", "nationalities" or "distinct societies" - is telling. The concept of nation is not merely a sociological one but is also normative, "carrying with it claims for self-determination" although this "does not, however, necessarily entail sovereign statehood" (Keating 2001, vii). Indeed, all multinationalists whose works I have examined stress that they do not endorse a proliferation of separatist tendencies and sovereign states (but some of do downplay the potential implications of secession). "In the end there is much of value in the plurinational state, and little to be gained from a world of more and more states", claims, for example, Tierney $(2004,339)$. Neil MacCormick is also clear on this point:

The attempt to match up nations with states, and then to accord sovereignty to each state may be the true source of the evils we perceive. [...] There cannot be a perfect match between the nations that exist in the world and any possible set of sovereign states that have absolute authority over exactly demarcated territories. [...] [I]f it is injudicious to increase excessively the number of states, it may in the alternative be possible to diminish their pretensions, and thus to adjust the position between those nationalities who have and those who have not a fully sovereign state of their own. (MacCormick 1996, 554, 566)

Multinationalists genuinely believe that the recognition of sub-state nations, by attributing them large self-government rights but not necessarily full sovereignty, might hinder separatist tendencies and the proliferation of sovereign states in the world (see also Guibernau 2006).

Yet the "fundamental challenge" of liberal theorists, as identified by Kymlicka, remains: what is the source of unity in the democratic multinational state? This challenge is fundamental, indeed, and it probably explains why some authors have difficulties to endorse the very concept of multinational state. It should not come up as a surprise that in November 2006 the first chamber of the Canadian parliament ("House of Commons") overwhelmingly passed a motion - that is, an unbinding 
political act - recognising the nationhood of Quebec, by stressing nevertheless that "the Québécois form a nation within a united Canada."24

Keating's "plurinationalist" approach is more differentiated and gives an interesting answer to this dilemma:

Plurinationalism is more than multinationalism, which could refer to the coexistence of discrete and separate national groupings within a polity. Under plurinationalism, more than one national identity can pertain to a single group or even an individual, opening up the possibility of multiple nationalities which in turn may be nested or may overlap in less tidy ways. (Keating 2001, 27)

I assume that this means, for instance, that Britain is a nation and that Scotland is a nation too and that, as a consequence thereof, a Scottish citizen can have both national identities. In this case the "source of unity" that holds Britain together is that it is a nation-state and a plurinational state at the same time. Indeed, David Miller $(2001,307)$ claims that Britain is a "single, but pluriform, nation." And even MacCormick does not deny (at least not explicitly) that there is a British nation: "Many people would say that there is also a 'British nation' that in some sense includes all the internal nations or parts of the United Kingdom" (MacCormick 1999a, 190).25

Keating, to be sure, does not argue along similar lines since he claims that the United Kingdom is truly plurinational. Nevertheless, this is implicit in his claim that in plurinational states people have multiple national identities. Moreover, it is interesting to note that both Keating $(2001,163)$ and Tierney (2004) quote the declarations of former British Prime Ministers John Major and Tony Blair who referred to Scotland or Wales as "nations." Keating and Tierney consider such declarations as a further proof that Scotland or Wales are officially recognised as nations. By using the same method we could quote the former British Prime Minister Gordon Brown, a Scot, who speaks of "British people", "patriotism" and tries to promote "Britishness" as "our [British] national identity":

While we have always been a country of different nations and thus of plural identities - a Welshman can be Welsh and British, just as a Cornishman or woman is Cornish, English and British - and may be Muslim, Pakistani or Afro-Caribbean, Cornish, English and British - there is always a risk that, when people are insecure, they retreat into more exclusive identities rooted in 19th century conceptions of blood, race and territory - when instead, we the British people should be able to gain great strength from celebrating a British identity [...] the question is essentially whether our national identity is defined by values we share in

24 See Henri Brun, "La motion Harper: peu mais tout de même pas rien", Le Devoir, 2 December 2006 (www.vigile.net/La-motion-Harper-peu-mais-tout-de, accessed 23 December 2010.)

25 However, in his works MacCormick did not (as far as I am aware) discuss the problem of shared identity in the post-sovereign order. 
common or just by race and ethnicity [...]. ${ }^{26}$ (Brown 2006; emphases added)

I believe that in the end of the day Keating's argument supports the idea that the United Kingdom is both a nation and a plurinational state. The same could be said of Spain or Canada. This argument resembles Miller's (2001) concept of "nested nationalities" or "nations-within-nations", to which MacCormick also implicitly refers. Miller believes that to call these polities multinational states is "misleading" and reserves the term multinational state for the states made up of two or more "rival nationalities", where the state is "either an instrument in the hands of one nations as in the case of Israel, or the arena where the rival nations jostle for advantage, as for example with Yugoslavia before its break-up, or many African states today" (Miller 2001, 307).

Now the problem is that this is precisely what most multinationalists - in the practice, if not in academy - do not want to concede. They insist, for instance, that Canada is not a nation and that its multinational character implies that it is composed of the two linguistic-territorial nations: Quebec and the "Rest of Canada" (sometimes called "English Canada") (Resnick 1994b). Seymour (1999, chap. 9) even insists that "Anglo-Quebeckers must identify themselves with the Quebec nation or leave the territory" (cited in Keating 2001, 162).

Keating (2001, 166) further asks: "How can we recognize difference while deepening and strengthening democracy?" Miller's (1995) answer is that democratic trust and practice are best founded on nationality.27 Miller "may be right", writes Keating (2001, 166-7), but it "assumes too easily that we know what the nation is or that governments should seek to foster a common identity based on the state. This would do violence to the very principles underpinning the plurinational state, in which nationality is recognized but is multiple, complex, and overlapping." I believe that Keating's view is excessively pessimistic on this point. Does Gordon Brown do violence to the "principles underpinning the plurinational state" if at the same time he recognises the plurinational character of the United Kingdom and underlines the importance that the British citizens should (also) share some kind of common British identity?

If some kind of overarching common national civic identity advocated, for instance, by Miller (1995) and Barry (1999), is considered as too invading, what would do the job? The often quoted Habermasian constitutional patriotism - also labelled the "postnational thesis" (see Abizadeh 2004, 239 ) - is seen as "too thin a basis for democratic deliberation, practice, and competition" (Keating 2001, 166-7). In my view, the same can be said of MacCormick's "post-sovereign" vision which does not really address the problem of unity and shared identity.

\footnotetext{
26 Gordon Brown, Speech by the Rt Hon Gordon Brown MP, Chancellor of the Exchequer, at the Fabian New Year Conference, London, 2006 (emphases added). www.fabians.org.uk/events/speeches/the-future-of-britishness, accessed 19 December 2010.

27 For a powerful critique of Miller's arguments see Abizadeh (2002).
} 
In the end of the day Keating suggests to opt for the "open politics" towards the concept of nationality. But such an approach stands in stark contrast with, for example, the tendency in Belgium "to reorganize the state in the form of sealed communities [for it means] to confine democratic deliberation and freeze communicative orders at a time of change and evolution. It risks divorcing deliberative communities from the evolving functional order, so repeating the problems of the nation-states" (Keating 2001, 167).

There are powerful reasons for subscribing to the "open politics" approach advocated by Keating. Indeed, one of the goals of an ideal-type liberal state in a more and more globalised and inter-connected world should be to allow for a fluid conception of identity, including the national identity. Probably no state has reached this ideal or ever will. ${ }^{28}$ But it does seem to be the most promising way for addressing the concepts of (multi-)nationality, shared identity and stability. And it shows that it is important to overcome a rigid and increasingly sterile distinction between mononational and multinational states.

Zentrum für Demokratie Aarau ZDA

University of Zurich

5000 Aarau (Switzerland)

E-Mail:nenad.stojanovic@zda.uzh.ch

\section{References}

Abizadeh, Arash. 2002. Does Liberal Democracy Presuppose a Cultural Nation? Four Arguments. American Political Science Review 96: 495-509.

Abizadeh, Arash. 2004. Liberal Nationalist versus Postnational Social Integration: On the Nation's Ethno-cultural Particularity and "Concreteness." Nations and Nationalism 10: 231-50.

Appiah, Kwame Anthony. 2007. Cosmopolitanism. Ethics in a World of Strangers. New York and

London: W. W. Norton \& Company. (1st ed. 2006.)

Barry, Brian. 1999. Statism and Nationalism: A Cosmopolitan Critique. In Global Justice: NOMOS

XLI. Ed. I. Shapiro and L. Brilmeyer, 12-66. New York: New York University Press.

Bauböck, Rainer. 2001. Multinational Federalism: Territorial or Cultural Autonomy? In Willy

Brandt Series of Working Papers in International Migration and Ethnic Relations. Malmö:

IMER.

28 A possible exception is Switzerland (see Stojanovic 2000, Dardanelli and Stojanovic 2011). The concept of "statenation," advanced by Alfred Stepan and Juan Linz in 1996 and further developed in recent years (see Stepan, Linz, and Yadav 2010), also goes beyond the mononational v. multinational dichotomy. According to this view, Switzerland and the United States are best seen as state-nations - that is, they "are culturally quite diverse, but [their] diversity is nowhere organized by territorially based, politically significant groups that mobilize nationalist demands for independence" (ibid., 58). 
Büchi, Christophe. 2000. “Röstigraben”. Das Verhältnis zwischen deutscher und französischer Schweiz. Geschichte und Perspektiven. Zurich: NZZ.

Burgess, Michael. 2006. Comparative Federalism. Theory and Practice. London and New York: Routledge.

Connor, Walker. 2005. The Dawning of Nations. In When is the Nation? Towards an Understanding of Theories of Nationalism. Ed. A. Ichijo and G. Uzelac, 40-6. London and New York: Routledge.

Dardanelli, Paolo, and Nenad Stojanovic. 2011. The Acid Test? Competing Theses on the Nationality-Democracy Nexus and the Case of Switzerland. Nations and Nationalism 17: 357-76.

Gagnon, Alain-G. 2001. The Moral Foundations of Asymmetrical Federalism: A Normative Exploration of the Case of Quebec and Canada. In Multinational Democracies. Ed. A.-G. Gagnon and J. Tully, 319-37. Cambridge: Cambridge University Press.

Guibernau, Montserrat. 2006. National Identity, Devolution and Secession in Canada, Britain and Spain. Nations and Nationalism 12: 51-76.

Ichijo, Atsuko, and Gordana Uzelac, eds. 2005. When is a Nation? Towards an Understanding of Theories of Nationalism. London and New York: Routledge.

Keating, Michael. 2001. Plurinational Democracy. Stateless Nations in a Post-Sovereignty Era. Oxford: Oxford University Press.

Kriesi, Hanspeter, Boris Wernli, Pascal Sciarini, and Matteo Gianni. 1996. Le clivage linguistique. Problèmes de compréhension entre les communautés linguistiques en Suisse. Bern: Swiss Federal Statistical Office.

Kymlicka, Will. 1995. Multicultural Citizenship. A Liberal Theory of Minority Rights. Oxford: Clarendon Press.

Kymlicka, Will. 1997. State, Nations and Cultures. Ottawa: Ottawa University, Department of Philosophy.

Kymlicka, Will. 1998. Finding Our Way. Rethinking Ethnocultural Relations in Canada. Toronto: Oxford University Press.

Kymlicka, Will. 2001. Politics in the Vernacular. Nationalism, Multiculturalism, and Citizenship. New York: Oxford University Press.

MacCormick, Neil. 1996. Liberalism, nationalism and the post-sovereign state. Political Studies 44: 553-67.

MacCormick, Neil. 1999a. Nation and Nationalism. In Theorizing Nationalism. Ed. R. Beiner, 189204. Albany: State University of New York. (1st ed. 1982.)

MacCormick, Neil. 1999b. Liberal nationalism and self-determination. In The Rights of Nations. Nations and Nationalism in a Changing World. Ed. D. M. Clarke and Ch. Jones, 65-88. New York: St. Martin's. 
Miller, David. 1995. On Nationality. Oxford: Oxford University Press.

Miller, David. 2001. Nationality in Divided Societies. In Multinational Democracies. Ed. A.-G. Gagnon and J. Tully, 299-318. Cambridge: Cambridge University Press.

Reinhardt, Karin. 2009. Mononationales Deutschland? Multinationale Schweiz? Eine Kritik an Will Kymlickas Theorie des Multikulturalismus. In CIS Working Papers. Zurich: Center for Comparative and International Studies.

Requejo, Ferran. 1999. Cultural Pluralism, Nationalism and Federalism: A Revision of Democratic Citizenship in Plurinational States. European Journal of Political Research 35: 255-86.

Resnick, Philip. 1994. Toward a Multinational Federalism: Asymmetrical and Confederal Alternatives. In Seeking a New Canadian Partnership: Asymmetrical and Confederal Options. Ed. L. F. Seidle, 71-94. Montreal: Institute for Research on Public Policy. Resnick, Philip. 2006. What Theorists of Nationalism Have to Learn from Multinational and Multilingual States. Paper presented at the 20th Congress of the International Political Science Association, Fukuoka.

Seymour, Michel. 1999. La nation en question. Montreal: L'Hexagone.

Smith, Anthony D. 2004. History and National Destiny: Responses and Clarifications. Nations and Nationalism 10: 95-209.

Stepan, Alfred. 2001. Arguing Comparative Politics. Oxford: Oxford University Press.

Stepan, Alfred, Juan J. Linz, and Yogendra Yadav. 2010. The Rise of "State-Nations”. Journal of Politics 21: 50-68.

Stojanovic, Nenad. 2000. The Idea of a Swiss Nation. A Critique of Will Kymlicka's Account of Multination States. McGill University, M.A. thesis.

Tierney, Stephen. 2004. Constitutional Law and National Pluralism. Oxford: Oxford University Press.

Van den Berghe, Pierre L. 2005. Ethnies and Nations: Genealogy Indeed. In When is the Nation? Towards an Understanding of Nationalism. Ed. A. Ichijo and G. Uzelac, 113-8. London and New York: Routledge.

Watts, Ronald L. 2000. Federalism and Diversity in Canada. In Autonomy and Ethnicity. Negotiating Competing Claims in Multi-ethnic States. Ed. Y. Ghai, 29-52. Cambridge: Cambridge University Press.

Young, Iris Mariom. 1997. A Multicultural Continuum: A Critique of Will Kymlicka's EthnicNation Dichotomy. Constellations 4: 48-62. 